\title{
HUMOR DAN KOMUNIKASI DAKWAH \\ PENGEMBANGAN MASYARAKAT ISLAM
}

Oleh

\section{Muniruddin}

\section{Abstrak}

Pembahasan ini meneliti corak dan fungsi humor dalam komunikasi dakwah dalam pengembangan masyarakat Islam. Tidak asing lagi mayoritas masyarakat pada umumnya menginginkan komunikasi itu diselingi atau disisipi dengan humor, sehingga seperti sebuah makanan mempunyai bumbu yang enak untuk dimakan, dan setelah audiens merasa senang dan terhibur tentu selanjutnya mereka akan mengambil perhatian penuh dari komunikan yang sedang memberikan wejangan dalam bentuk tujuan komunikasi dakwah yang diterapkannya. Masyarakat islam pada umumnya kelas menengah ke bawah dalam bidang ekonominya, masyarkat banyak bekerja di daerah pertanian, nelayan, guru, bisnis, perkantoran dan lain sebagainya. Dalam mengelola pekerjaan sering menimbulkan lelah, jenuh dan mendapat kesulitan kesulitan. Dengan adanya isian rohani lewat pendengaran dari komunikasi yang berbentuk dakwah uang humoris dapat merangsang dan menghibur masyarakat sekaligus mereka mendapat tambahan ilmu pengetahuan.

Kata kunci : humor, komunikasi dakwah, pengembangan masyarakat Islam.

\section{PENDAHULUAN}

Dalam menjalani hidup dan kehidupan manusia mengalami berbagai macam corak dan ragam dari segi penghidupan dan komunikasi. Manusia sebagai makhluk pribadi dan sosial tidak bisa hidup sendiri, namun tergantung dengan lingkungan sekitarnya, diantara cara seseorang berhubungan dengan orang lain adalah dengan cara berkomunikasi yang dapat dimengerti satu sama lainnya.

Komunikasi yang baik adalah komunikasi dua arah, antara komunikator dan komunikan saling memahami dan menyimak dialog dengan baik dan terus mengikutinya dengan cermat dan menimbulkan asumsi yang dapat menyenangkan hati antara komunikator dan komunikan. Maka dalam hal inilah timbul ide-ide untuk 
menimbulkan rangsangan yang harmonis dalam setiap komunikasi yang menyenangkan dalam setiap pembicaraan.

Pada bahasan ini penulis mencoba menganalisis beberapa referensi yang berkaitan dengan humor dan keomunikasi, dalam hal ini Penulis mencoba mengkaitkannya dengan komunikasi Islam dan menganalisis sejauh mana data statistik pengaruh humor dalam berkomunikasi pada pariwisata. Dalam hal ini pemandu mengambil teknik analisis dengan cara rekaman audio dan visual untuk meneliti sejauh mana tingkat kesenangan dan kegemaran para audiens yang sedang mendengar sebuah komunikasi dakwah yang dalam komunikasi tersebut diselitkan diantara aneka humor yang menggugah dan menghidupkan suasana komunikasi antara komunikator dengan komunikan, seperti bentuk jenaka atau berseloroh, cerita lucu, mengusik atau melawak, perlingan, sindiran, dan kelakar. Dikaitkan dengan komunikasi Islami, apa kaedah hukum humor dalam ucapan, sejauh mana batasan humor yang dibolehkan dalam komunikasi Islam.

Maka dalam tulisan ini dapat Penulis rumuskan rumusan masalah :

1. Apa yang dimaksud dengan humor,

2. Sejauh mana pengaruh humor dalam komunikasi

3. Bagaimana humor yang baik dapat menimbulkan gelak dan tawa ditinjau dari etika dan akhlaq untuk pengembangan masyarakat Islam

4. Bagaimana analisis tentang humor dan komunikasi.

\section{A. PEMBAHASAN}

\section{Pengertian.}

Berbagai macam pendapat dan pengertian tentang humor, ada yang berpendapat bahwa humor adalah sebuah cerita pendek yang menceritakan suatu kejadian yang lucu dengan harapan dapat memuat pembacanya tertawa. Apa pula yang mengartikan humor sama dengan komedi yaitu sebuah imitasi dari kejelekan kejelekan manusia yang didramatisir sehingga menimbulkan tawa. Kemampuan mentertawakan kondisi sekitar diri sendiri, pilihan sendiri, menjadi salah satu katup yang akan melancarkan kembali kemampaatan hidup merupakan humoris. Kelucuan sebuah humor dapat disebabkan oleh beberapa hal, misalnya kelakuan para pelaku, kejadian yang umum akan tetapi 
dipelesetkan, kritik terhadap keadaan, kebodohan, kesalahpengertian, benturan antara budaya dan hal hal lain. ${ }^{1}$

Hidup ini tidak boleh terlalu serius, harus ada saat saat senggang, santai, tersenyum. Melempar joke joke, basa basi, walau hanya sebentar. Tujuannya agar hidup selalu bergairah, semangat, termotivasi, fresh dan yang paling penting tidak bosan memulai dan menjalani hari hari panjang penuh kesibukan yang terkadang monoton dan menjemukan.

\section{Humor dan Komunikasi.}

Humor secara umum dapat dibagi kepada dua bagian, yaitu : adaptif dan humor maladaftif. Humor adaptif ialah yang berhubungan dengan tingginya selfesteem, rendahnya tingkat depresi dan kecemasan dan penilaian selfcompetence yang dimiliki individu, jenis humor ini adalah bersifat positif, sdengkan humor maladaptif dihubungkan dengan menurunnya self-esteem, tingginya depresi dan kecemasan, menurunnya penilaian trhadap self competence individu, jenis humor ini adalah humor yang bersifat negatif.

Penggunaan humor adaptif berhubungan dengan konsep diri yang positif dibandingkan dengan humor maladaptif, humor juga dapat digunakan sebagai alat untuk menyelasikan masalah krisis identitas. Sejauh ini humor merupakan aya yang aman untuk berurusan dengan emosi negatif seperti rasa takut dan malu. $^{2}$

Humor dapat dibedakan dalam bentuk ekspresi, yaitu :

a. Humor personal, yaitu lebih mengarah pada perilaku tertawa paa diri sendiri, seperti jika melihat pohon berbentuk mirip orang yag sedang buang air besar, dan lain sebagainya.

b. Humor dalam pergaulan, terjadi ketika adanya senda gurauan atau lelucon yang dibahas diantara teman saat mendengar ceramah atua pidato di depan umum,

c. Humor dalam kesenian, yang terbagi kepada :

$\checkmark$ Perlakuan, seperti antonim

\footnotetext{
${ }^{1}$ Muhammad Yasir, Humor Sehat ala Ustadz, Pustaka al Kautsar, Jakarta, 2012, hal. 1

2 A.Gillian, Kirsh, Humor Generation And Reception: Relationships With Self-Concept And
} Well Being, 2005, hal. 205 
$\checkmark$ Grafis, seperti kartun, karikatur, foto jenaka dan lain lain

$\checkmark$ Literatur, seperti cerpen, sajak jenaka, dan sebagainya.

Humor sebagai komunikasi dapat dibagi kepada tiga jenis, yaitu :

a. Komunikator bermaksud untuk mengatakan hal hal yang lucu, sedangkan komunikan bertindak sebagai orang yang menerima lelucon tersebut dengan tertawa.

b. Komunikator tidak bermaksud untuk melucu, namun komunikan memberikan respon lucu dengan tertawa atau hanya tersenyum

c. Komunikator bertujuan untuk melucu, namun komunikannya tidak memberikan respon lucu dengan tidak tertawa atau tidak mau tersenyum.

Jika dikaitkan humor dengan komunikasi, ada yang bersifat verbal, visual dan auditif. Jika ditinjau dari segi materi sering terfokus kepada humor politis, seks, sadis dan teka teki. Jenis humor dari segi etis terbagi atas humor sehat atau berpendidikan dan tidak sehat atau tidak mendidik.

\section{Fungsi Humor}

Terlepas dari berbagai macam perbedaan perbedaan pendapat dalam medefinisikan humor, atau semakna dengannya seperti canda, lelucon, kocak dan lain sebagainya, secara umum humor berfungsi :

a. Kritik elastis, yaitu humor sebagai alat untuk melakukan protes sosial. Dengan fungsi ini humor bisa dilihat sebagai alat untuk melihat realitas di masyarakat, karena humor dapat dengan leluasa mamsuki semua wilayah yang ada dalam masyarkat, dia bisa masuk pada elit politik dan juga bisa masuk dalam golongan masyarakat biasa. Seperti kata kata Zainuddin dalam ceramahnya. Sulitnya mencari keadailan, ada pulus mulus, kalau tidak ada pulus manfus, jangan sampai para penegak hukum kita terjebak lagu baru "maju tak gentar membela yang bayar"

b. Menjadi media, yaitu humor menjembatani kepentingan pemerintah kepada rakyatnya dan rakyat kepada pemerintahnya, karena sering banyak hal yang tidak terkomunikasikan dengan baik antar keduanya sehingga sering menimbulkan konfik yang tentunya merugikan kehidupan berbangsa dan bernegara.

c. Melihat kualitas demokrasi suatu bangsa, semakin berkembang humor pada suatu masyarakat maka semakin dewasa masyarakat tersebut, semakin 
banyaknya humor berkembang dalam masyarakat menunjukkan masyarakat sudah dewasa, jadi jika ada humor ditanggapi dengan kemarahan dan emosi berarti dia belum dewasa, hal ini terkait dengan sikap suatu bangsa dalam menyikapi kritik, terutama kritik membangun yang disampaikan melalui media humor.

d. Menjadi hiburan, humor positif menjadi hiburan dan strategi untuk melancarkan komunikasi, karena terhibur maka komunikasi bertambah semarak, menimbulkan gelak dan tawa, menambah semganat kerja, akhirnya dapat hasil yang dituju.

e. Menimbulkan kemesraan, humor yang baik menimbulkan bahagia dan senang dihati sehingga antara komunikator dan komunikan dapat bekerjasama dengan baik, santai dan mesra, serta dapat mengatasi tekanan dan stres.

f. Humor juga berfungsi melestarikan kesehatan, karena humor dapat meningkatkan produksi sel natural killer, sel ini berfungsi untuk menjaga imun tubuh dalam melawan virus, bakteri dan tumor. ${ }^{3}$

\section{Analisis Penulis}

Sepanjang pengamatan penulis tentang berkomunikasi yang mengandung humor itu lebih mendapat perhatian ketimbang pembicaraan atau komunikasi yang monoton dan serius tanpa diselipkan humor, ibaratnya sebuah makanan akan lebih menarik jika bumbunya diolah pada masakan yang berpariasi dan menimbulkan rasa dan aroma yang spesial. Apabila bumbu yang disuguhkan itu sesuai dengan selera konsumen tentu makanan itu digemari dan menjadi idola untuk dipesan dan dinikmati. Dalam hal ini penulis mengambil beberapa sampel penelitian tentang humor ;

a. Sebuah penelitian di Kuala Lumpur Malaysia pada Jurnal Komunikasi yang terbit tahun 2017 "Malaysian Juorunal of Communication" Jilid ke 33, bagaimana pengaruh humor pada komunikasi terhadap para pariwisata asing yang berkunjung ke Kuala Lumpur Malaysia. Kesimpulan dalam jurnal tersebut menunjukkan hasil menunjukkan pelancong asing yang datang ke Kuala Lumpur Malaysia khususnya warganegara Jepang berbahasa Jepang

${ }^{3}$ James Powell Thorson, FC,dkk, Psychological Health And Sense Of Humor, dalam Jurnal Of Clinical Psychology, vol. 35 (8) hal. 60 
dalam tenggang waktu selama 18 tahun terakhir, yaitu mulai dari $1998 \mathrm{sd}$ 2015, dimulai dari bulan agustus terdapat 607 orang sebagai guide pemandu pariwisata berbahasa Jepang di Kuala Lumpur Malaysia. Rekaman audio visual Sesi Lawatan Pemandu Pelancong (SLPP) Dan pemerhatian semasa interaksi pemandu pelancong dengan pelancong Jepang di Kuala Lumpur Malaysia dari rentang waktu 26 jam 56 menit, terdapat 48 kali humor sehat. Hasilnya 26 × $60+56=1616: 48=33$, 66. Maka rata-rata setiap 33 menit, guide pemandu menyelipkan satu kali humor yang terdiri dari 7 macam bentuk humor, yaitu : ada yang berbentuk jenaka atau seloro $38 \%$, humor dalam bentuk penceriaan sebanyak $21 \%$, melalui usikan atau lawakan sebanyak $21 \%$, melalui perlian $10 \%$, dengan bahasa sindiran gelitik $6 \%$, melalui penukaran kod potret $2 \%$ dan berkelakar sebanyak $2 \%$. Dari data yang ada menunjukkan bertambahnya semangat dan jumlah kunjungan pariwisata ke Kuala Lumpur Malaysia.

b. Orator terkenal Indonesia dalam bidang dakwah Islam KH. Zainuddin MZ (1987 - 2013) yang dikenal dengan Muballigh Sejuta Umat atau Da’i Sejuta Umat. Naik turunnya pamornya sering diincar dengan selingan humornya yang ilmiah dan mendidik, sehingga tidak membosankan para mad'u untuk mendengarkannya.

\section{Humor Pada Komunikasi Islam}

Dalam Islam perinsipnya selalu mempermudah dalam setiap urusan, tidak pernah bertele tele dan tidak pernah mempersulit, sebagaimana firman Allah SWT :

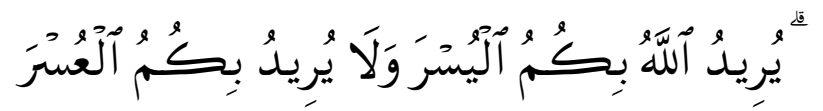

Artinya : Allah menghendaki kemudahan bagimu, dan tidak menghendaki kesukaran bagimu. QS Al Baqarah 185

Karena banyaknya kegiatan dan persoalan manusia yang dihadapinya dalam menjalani hidup dan kehidupan, maka tidak jarang mengalami kebuntuan dan kesulitan dan kesusahan. Justru itu Allah menerapka syari'at Islam bagi penganutnya untuk mendapatkan stabilitas dan ketentraman jiwa serta kemakmuran hambaNya, allah selalu menciptakan alam dalam bentuk 
berpasang-pasangan dan mengiringi setiap ada kesukaran dengan kemudahan, sebagaimana firmanNya :

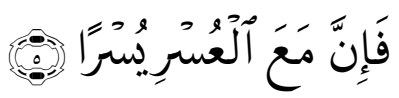

Artinya : karena Sesungguhnya sesudah kesulitan itu ada kemudahan, QS. Al Insyarah 5

Perjalanan hidup dan kehidupan ini dijalani dengan serius ada juga yang tidak serius, antara serius dan tidak serius ada keunikan-keunikan yang membuat kita lucu dan menggelikan. Allah memberikan gambaran keunikan pada perjalanan Nabi Sulaiman ketika mengenderai kudanya dalam sebuah rombongan, sehingga Nabi Sulaiman tertawa mendengar dan melihat keadaan yang ada, seperti yang di firmankanNya dalam surah an Namal 19



Artinya : Maka Dia (sulaiman) tersenyum dengan tertawa karena (mendengar) Perkataan semut itu. dan Dia berdoa: "Ya Tuhanku berilah aku ilham untuk tetap mensyukuri nikmat mu yang telah Engkau anugerahkan kepadaku dan kepada dua orang ibu bapakku dan untuk mengerjakan amal saleh yang Engkau ridhai; dan masukkanlah aku dengan rahmat-Mu ke dalam golongan hamba-hamba-Mu yang saleh".

Nabi Sulaiman tertawa kagum terhadap kewaspadaan dan peringatan yang diberikan semut itu kepada kawan kawannya serta hidayah yang ditanamkan Allah pada semut itu, disamping merasa gembira dengan apa yang telah diberikan Allah kepadanya secara khusus berupa pemahaman terhadap maksud semut itu. Sulaiman berkata : ya Tuhanku berilah aku ilham untuk mensyukuri nikmat yang telah Engkau limpahkan kepadaku dan kepada kedua orang tuaku serta untuk mengerjakan amal yang Engkau sukai dan ridhai, matikanlah aku 
dalam keadaan bersrerah diri kepadaMu dan masukanlah aku dalam golongan para hambaMu yang shalih. ${ }^{4}$

Dari penafsiran al Maraghi dapat dipahami bahwa :

1. Nabi Sulaiman kagum melihat adanya tanggungjawab ketua semut untuk menyelamatkan para rekannya

2. Nabi Sulaiman berlindung kepada Allah dari sifat semut yang sudah buruk sangka terhadapnya dan para rombongannya yang akan melintasi daerah semut tersebut. Hal ini dipahami oleh Sulaiman, karena semut hanyalah seekor hewan kecil yang tidak dilengkapi Allah dengan akal dan agama, justru itu Nabi Sulaiman menguntaikan do'a ya Allah..! berilah aku ilham untuk pandai menyukri nikmat akal dan agama yang telah diberikan Allah kepada manusia.

Allah menciptakan para Nabi sebagai uswatun hasanah, bahwa kita harus menunjukkan experessi diri ketika melihat sesuatu yang unik dan ada kekuatan super yang dibangun untuk suatu kepentingan, Nabi Sulaiman respon sampai-sampai dia tersenyum dan tertawa atas aksi seekor semut terhadap para anggotanya. Toh seekor semut yang tidak punya akal dan didikan dapat menggugah hati manusia, kenapa seorang manusia tidak mampu untuk memotivasi para audien dalam satu bentuk gambaran positif yang menghibur agar audien termotivasi dan tetap menaruh perhatian kepada komunikan.

Bagaimana humor yang baik dapat menimbulkan gelak dan tawa ditinjau dari etika dan akhlaq islami. Pada syari'at Islam barometernya adalah Rasulullah SAW. Bahwa candaan Rasulullah SAW mengandung kebenaran tiak ada dusta dan tidak pula menghina atau mencela orang lain dan tidak menyinggung orang yang diajak bercanda, sebagaimana terdapat dalam sebuah hadis :



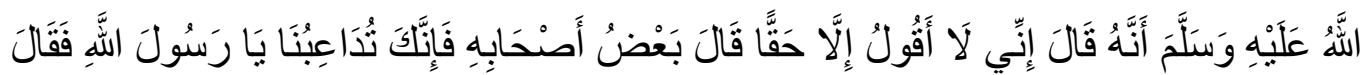

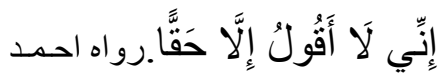

Artinya : Telah menceritakan kepada kami Yunus telah menceritakan kepada kami Laits dari Muhammad dari Sa'id bin Abi Sa'id dari Abu Hurairah dari Rasulullah shallallahu 'alaihi wasallam, beliau bersabda: "Aku tidak berkata

${ }^{4}$ Ahmad Mushthafa Al Maraghi, Tafsir al Maraghi, CV. Tooha Putra Semarang, 1993, hal. 239 
kecuali kebenaran, " sebagian sahabatnya berkata; "Sesungguhnya engkau bercanda dengan kami wahai Rasulullah, " maka beliau bersabda: "Aku tidak berkata kecuali kebenaran." HR. Ahmad, hadis No. $8125^{5}$

Humor dan canda Rasulullah SAW bersifat membangun dan memotivasi, diantara humor dan canda Rasulullah SAW :

1. Ketika makan buah kurma bersama-sama dengan sahabat Ali bin Abi Thalib.

Pada satu hari Nabi SAW, Ali Bin Abi Thalib dan para sahabat lainnya makan kurma bersama sama, pada saat makan kurma itu biji kurma bekas Ali digesernya ke depan Nabi, ketika makan makan kurma bersama hampir selesai, Ali berkata sambil bertanya; siapa yang paling banyak dan lahab diantara kita makan buah kurma hari ini..? masing-masing melihat bekas makanannya, ternyata dihadapan Nabi biji kurma yang paling banyak, semua tersenyum melihat ke arah Nabi, dengan arti kata bahwa Nabi yang paling banyak melahab kurma, karena kadong semua mata tertumpu kepada Nabi, Nabi menjawab, saya walaupun banyak makan kurma tapi tidak ikut sama bijinya, tapi kalau ada yang makan sama bijinya itu tentu itu yang paling lahab dan sangat lapar. Maka perhatian kembali kepada Ali, karena biji kurmanya tidak ada dihadapannya. Maka semua pada tertawa, karena kelakar Nabi SAW.

2. Nenek nenek tidak ada di syurga.

Pada satu hari dalam sebuah majelis, ada seorang nenek nenek bertanya kepada Rasulullah, ya Rasul apakah saya masuk surga..? lalu Rasulullah menjawab; maaf nek, orang yang sudah tua (nenek nenek) tidak ada di dalam syurga, belum selesai Rasulullah bicara, nenek nekek itu menangis dan kelihatan sangat sedih. Rasulullah melanjutkan ucapannya, di syurga nek nanti umur manusia mudamuda umurnya berkisar antara 30-35 tahun, cantik, ganteng. Mendengar ucapan Rasulullah itu barulah nenek itu gembira dan tersenyum dan para sahabat pada tertawa.

3. Sakit mata dan makan kurma.

Pernah Ali sakit mata dan duduk duduk bersama dengan Nabi SAW, kemudian ada sahabat yang membawakan kurma untuk dimakan, kurma dipersilakan untuk diambil dan dimakan, ketika masing masing mengambil kurma dan langsungg

${ }^{5}$ Ahmad bin Muhammad bin Hanbal, Musnad Ahmad, Terj. Fathurrahman Abdul Hamid, dkk., Pustaka Azzam, Jakarta, 2007, hal. 670 
memakannya, Nabi bertanya kepada Ali, kenapa kamu Ali makan kurma sedang matamu sakit..?, maka sepontan Ali menjawab; ya Rasul saya makan dengan sebelah mata saya yang masih sehat.. Nabi melihatnya dan sambil tertawa bersama sahabat lainnya.

4. Ganjalan satu batu dan dua batu.

Sewaktu akan perang khandaq terjadi, Rasulullah dan para sahabatnya bekerja keras menggali parit khandaq untuk pertahanan kaum muslimin di Madinah, pada saat mereka bekerja ada seorang sahabat yang merasa lapar dan haus sekali sampai sampai dia mengganjal satu batu diperutnya, sahabat tersebut mendekati Rasul dan berkata; ya Rasul, kita belum makan dan untuk menahan lapar aku ganjal perutku dengan sebuah batu dan dia membuka bajunya sambil memperlihatkan kepada Rasulullah, spontan Rasulullah sambil tersenyum menyingkap baju dan terlihat pula ada dua batu yang telah diganjalkan oleh Rasulullah diperutnya, sahabat tersebut dan juga sahabat lainnya melihat sambil tertawa.

Firman Allah SWT pada surah an Najm 43 :



Artinya : dan bahwasanya Dialah yang menjadikan orang tertawa dan menangis, Humor memang cara yang efektif untuk tetap mempertahankan perhatian audience dalam berkomunikasi, dapat menghibur seseorang dikala terasa sangat serius dan tegang dalam menjalani hidup dan kehidupan, namun ada beberapa hal yang tidak pantas di slipkan humor, seperti :

1. Membicarakan masalah tauhid aqidah ummat,

2. Memberikan nasehat kepada orang yang ditimpa musibah

3. Ketika membacaka ayat-ayat suci, dan membicarakan hukum-hukum ibadah mahdhah kepada Allah SWT.

4. Candaan dusta, menyebut hal hal yang tabu, mencela, menyinggung dan menghina orang atau kata kata yang tidak etis.

5. Humor yang mengandung unsur unsur membuka aib seseorang atau bersifat forno dan SARA. Sabda Rasulullah SAW : 


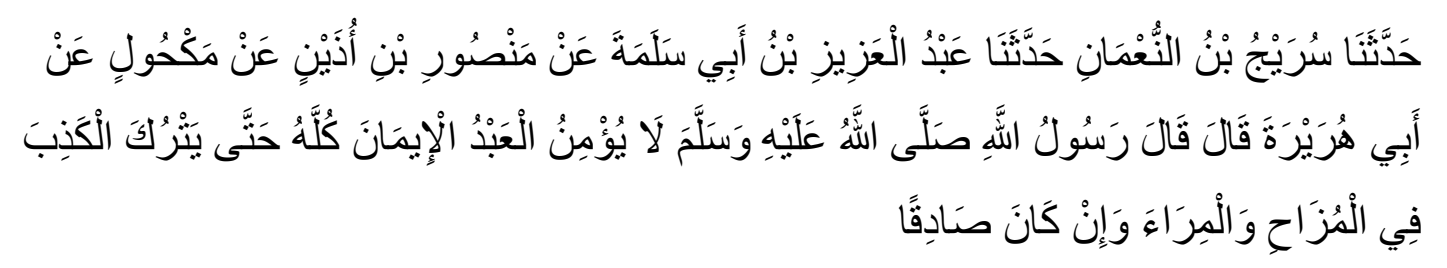

Artinya : Telah menceritakan kepada kami Suraij bin An Nu'man berkata; telah menceritakan kepada kami Abdul 'Aziz bin Abu Salamah dari Manshur bin Udzain dari Makhul dari Abu Hurairah berkata; Rasulullah shallallahu 'alaihi wasallam bersabda: "Seorang hamba tidak akan bisa beriman dengan sempurna sehingga ia bisa meninggalkan bohong baik dalam humor maupun debat, meskipun ia benar.HR Ahmad, hadis No. $8411^{6}$

\section{Analisis Humor Dalam Komunikasi Islami.}

Hidup terasa hambar dan datar tanpa humor dan canda, bagaikan makan tanpa rasa, dalam makanan tersebut ada manis, pahit, asam dan sebagainya, untuk menjalani hidup ini kita perlu enjoy, rilek dan selalu ceria dan bahagia agar tidak stres menghadapi kehidupan ini yang sebenarnya tidak berat, tapi sering dibuat berat oleh diri kita sendiri. Liku-liku dan gelombang kehidupan memperlihatkan kuantitas, kualitas dan penyajian tertentu akan menjadi penyedap dalam kehidupan.

Suatu kali Imam al Ghazali melontarkan enam pertanyaan kepada murid muridnya yang hadir dalam satu majelis taklimnya, salah satu diantara pertanyaannya; benda apa yang paling tajam di dunia ini..? para muridnya menjawab, pisau, ada yang menjawab silet, pedang dan lain sebagainya. Al Ghazali menanggapi jawaban murid muridnya tersebut, betul semua benda yang kalian sebutkan itu tajam, tapi ada yang lebih tajam dari itu, yaitu "lidah". Meskipun lidah tidak bertulang, namun lidah bisa lebih tajam dari apapun, karena dia bisa merobek hati, bahkan kadang lidah bisa membuat lubang menganga di hati lawan bicara yang mungkin perlu waktu lama untuk mengembalikannya ke kondisi semula. ${ }^{7}$

Ada sebuah dialog shahabat dalam riwayat Tirmizi, apakah wajah Rasulullah itu seperti pedang..? sahabat terseut menjawab, tidak, wajah Rasulullah itu seperti bulan. Wajah Rasulullah SAW ditamsilkan dengan bulan, bukan pedang, bukan pula seperti matahari, ini menunjukkan bahwa Rasulullah SAW berkarakter lembut, santun dan

\footnotetext{
${ }^{6}$ Sofware, Kutubuttis'ah, Canda Rasululah, Musnad Ahmad, hadis No. 8411

${ }^{7}$ Al Ghazali, Ihya Ulumuddin, Terj. Moh. Zuhri, dkk., Jld. II, CV. Asy Syifa', Semarang, 1990, hal. 321
} 
selalu membuat orang lain nyaman dan bahagia saat berada di sampingnya. Sebagaimana yang diceritakan oleh Ali bin Abi Thalib bahwa Rasulullah SAW adalah orang yang selalu gembira dan bersikap simpatik, beliau sering tersenyum ketika bersama para sahabat dan kadang-kadang tertawa sampai terlihat gigi taringnya. Sebagaimana yang dijelaskan oleh Ummul Mukminin Aisyah, sesungguhnya Rasulullah bila berada di rumah, beliau adalah orang yang lembut, tersenyum dan tertawa. Dan pernah diingatkan oleh baginda dalam satu riwayat : tidak baik orang yang tidak bersukaria, dan juga tidak baik orang yang tidak memberi kegembiraan kepada orang lain. "Rasulullah shallallahu 'alaihi wasallam senantiasa ceria dan keringatnya bagaikan kilau mutiara. HR. Muslim, hadis No. $4299^{8}$

\section{B. PENUTUP/KESIMPULAN}

Humor merupakan sebuah imitasi dari kelakuan manusia atau penomena alam yang didramatisir jadi lucu sehingga menimbulkan gelak dan tawa. Dari analisis ini dapat berarti Humor berpaedah dalam berkomunikasi, karena menjadikan suasana dialog komunikasi dua arah antara komunikator dengan komikan lebih disenangi, sifatnya santai dan mesra.

Humor yang dimaksud adalah yang etis sesuai dengan kaedah dan norma-norma agama, tidak merendahkan dan menghina seseorang, sifatnya jujur dan membangun. Dalam komunikasi Islam di ajarkan agar seseorang berusaha dengan baik, diantara kebaikan itu adalah dapat memotivasi diri sendiri dan orang lain, dalam bentuk motivasi ini disisipkan atau diselipkan humor yang sifat menggembirakan dan membangkitkan gairah kerja, sehingga dengan adanya gairah kerja pada gilirannya akan mendapat hasil yang menyenangkan untuk berdakwah pengembangan masyarakat Islam.

\footnotetext{
${ }^{8}$ Sofware Kutubussittah, sifat-sifat Rasulullah SAW
} 


\section{REFERENSI}

Al Qur'an al Karim,

Ahmad bin Muhammad bin Hanbal, 2007. Musnad Ahmad, Terj. Fathurrahman Abdul Hamid, dkk., Pustaka Azzam, Jakarta.

Al Maraghi, Ahmad Mushthafa, 1993. Tafsir al Maraghi, CV. Toha Putra Semarang.

Ghazali, Al, 1990. Ihya 'Ulumuddin, Terj. Moh. Zuhri, dkk., Jld. II, CV. Asy Syifa', Semarang.

Haris Kurniawan, 2017. Aksi Kocak Nuruddin, Tinta Median, Solo.

James Powell Thorson, FC,dkk, 1997. Psychological Health And Sense Of Humor, dalam Jurnal Of Clinical Psychology, vol. 35 (8).

James Hooke \& Jeremy Philips, 1997. Siasat Menyampaikan Pesan Dengan Tepat,alih bahasa Wahyudi, Kentindo Publisher, Jakarta.

Kirsh, Gillian, A. 2005. Humor Generation And Reception: Relationships With SelfConcept And Well Being.

Yasir, Muhammad, 2012. Humor Sehat ala Ustadz, Pustaka al Kausar, Jakarta.

Sofware Kutubuttis'ah. 